\title{
Los testamentos traicionados de Jorge Luis Borges: una lectura de La memoria de Shakespeare
}

\author{
DANIEL RODRÍGUEZ MARTÍNEZ \\ Universidad Autónoma de Madrid
}

Resumen: Borges siempre estuvo muy atento a la repercusión y a la aceptación de su obra; de ahí, que probablemente hacia el final de su vida dicha preocupación se acentuase hasta el punto de llegar a convertirse en un motivo literario, ya que "cuando se acerca el fin, ya no quedan imágenes del recuerdo; sólo quedan palabras» (Borges, 1989: I, 543-544). Esto culminó con la elaboración de una especie de testamento literario, proyecto que ya rondaba en su cabeza mucho antes, a comienzos de los años sesenta, según palabras de su biógrafa María Esther Vázquez. A la luz de esta idea proponemos una lectura personal de la última recopilación de cuentos del autor argentino, que, además, dentro de la bibliografía borgeana suele recibir menos atención.

Palabras clave: lectura, reflexión, diálogo, legado.

\section{Testaments betrayed of Jorge Luis Borges: A reading of La memoria de Shakespeare}

Abstract: Borges always looked after the resonance and reception of his work. At the end of his life such a concern was acute enough as to become a literary topic since «cuando se acerca el fin, ya no quedan imágenes del recuerdo; sólo quedan palabras» (Borges, 1989: I, 543-544). This led to the development of a kind of literary testament, project that already haunted his mind earlier, at the beginning of the sixties, according to his biographer María Esther Vázquez. Following this guideline, we sketch a new personal reading of his last collection of stories, which, by the way, has received so far much less critical appraisal than the previous ones.

Keywords: reading, reflection, dialog, legacy. 
Palabras, palabras desplazadas y mutiladas, palabras de otros, fue la pobre limosna que le dejaron las horas y los siglos «El Inmortal», J. L. Borges

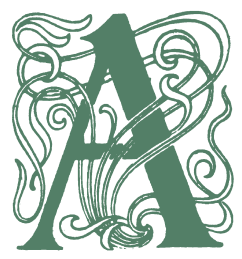

lo largo de la historia todo aquel que se ha visto subyugado por un afán creador ha convivido, de manera irremediable, con su condición de «efebo» en el ámbito de las letras. De ahí que todo escritor haya tenido siempre conciencia de que «de otro fue la palabra antes que mía» (Cuesta, 2003: 98). Dicha noción no solo ha desencadenado diversas actitudes en los nuevos autores, sino que ha terminado condicionando las distintas propuestas literarias que han ido surgiendo con el paso de los años, basadas siempre en planteamientos anteriores (bien con el fin de transgredirlos, bien con el de emularlos). Por ello, se ha llegado a reclamar la necesidad de «dejar de pensar en todo poeta como un ego autónomo, por solipsista que pueda ser el poeta más fuerte. Todo poeta es un ser atrapado en una relación dialéctica (transferencia, repetición, error, comunicación) con otro poeta o poetas» (Bloom, 1973: 130). Ahora bien, para Harold Bloom, ese diálogo genera tal zozobra en el joven creador que este termina obsesionado con la idea de «persuadirse (y persuadirnos) de que la palabra del precursor se gastaría si no se redimiera como una Palabra nuevamente consumada y aumentada del efebo» (1973: 110). No obstante, uno de los poetas polacos de mayor prestigio a nivel internacional del siglo pasado (no mencionado por el norteamericano), Zbigniew Herbert (1924-1998), no parece coincidir con esa postura tan desasosegante que supuestamente experimenta todo creador que no ha alcanzado aún su plenitud. Es más, la actitud de aquel hacia los clásicos dista mucho de adquirir las connotaciones negativas que se podrían extraer de la teoría de Bloom y, curiosamente, sus palabras fueron pronunciadas el mismo año de la controvertida publicación de The Anxiety of Influence: A Theory of Poetry (véase Herbert, 1973: 12). En cualquier caso, más allá de toda polémica, lo que parece incuestionable es la continuidad que se establece entre unos autores y otros. Tanto es así que algunos especialistas en literatura comparada han querido ir un paso más allá, como se desprende del sugerente título que han elegido para su monografía, Lo que Borges enseñó a Cervantes: Introducción a la literatura comparada (2016). 
Al igual que Herbert y tantísimos otros escritores, Jorge Luis Borges (18991986) declaró siempre que pudo su admiración hacia sus predecesores literarios (su obra está plagada de alusiones librescas). Tal era su devoción hacia estos que, según se cuenta, le parecía una aberración guardar sus publicaciones personales junto a las de sus maestros. Más allá de la autenticidad de esta anécdota, el argentino cuenta con más de una veintena de títulos propios y otros tantos en colaboración, entre los cuales cabría destacar las dos colecciones que le concedieron el reconocimiento unánime de la crítica y del público, Ficciones (1944) y El Aleph (1949). Con todo, a pesar de la fama que lo acompañó desde entonces hasta su muerte y de su inagotable capacidad creativa, su pasión por la lectura jamás cedió ni un ápice (incluso cuando la sombra se cernió sobre sus ojos, contratiempo que lo obligó a leer con los de sus allegados). Es más, llegó a coquetear con la posibilidad de que el universo fuese una biblioteca «ilimitada y periódica» (Borges, 1989: I, 471) ${ }^{1}$, razón por la que se declaraba un «aprendiz», esto es, «un lector» cuya «tarea», comprende, «es ilimitada/ y ha de acompañarme hasta el fin» (II: 394).

De este modo, si se considera su contribución sobresaliente a la «Biblioteca de Babel», la importancia que otorgaba a la lectura ${ }^{2}$ y la fama con que contó durante buena parte de su carrera, no sería quizás muy aventurado plantearse la posibilidad de que Borges se detuviese a reflexionar sobre el legado que dejaría a la posteridad y en cómo lo haría - en un afán de continuar con la dialéctica de la que hablábamos al principio. De hecho, su biógrafa María Esther Vázquez, con motivo precisamente de un artículo sobre «La memoria de Shakespeare», rescata unas palabras del escritor argentino - pronunciadas a comienzos de los años sesenta - sobre sus intenciones de futuro, que pueden contribuir al sentido de nuestra lectura. En ellas, Borges afirmaba que «[...] "antes de morir [...] querría escribir por lo menos tres libros más: uno, sobre los orígenes de la poesía en Inglaterra [...]; otro, sobre Shakespeare, y un tercero que sería una especie de testamento literario" " (Vázquez, 1990: 479, el subrayado es nuestro). En torno a esta última idea intentaremos proponer

\footnotetext{
1 De ahora en adelante todas las referencias a la producción borgeana procederán de sus Obras Completas. Dado que estas se dividen en tres tomos publicados el mismo año, las citas se anotarán entre paréntesis con dígitos romanos para aludir al volumen y, con numeración arábiga, al número de la página correspondiente.

2 «Que otros se jacten de las páginas que han escrito;/ a mí me enorgullecen las que he leído» (II: 394). En «Utopía de un hombre que está cansado» observamos la siguiente sentencia: «no importa leer sino releer» (III: 53-54).
} 
una interpretación de su recopilación final de cuentos, dado que no coincidimos con Vázquez en que Borges «no escribió ninguno de los tres» (1990: 479), sino que más bien creemos que La memoria de Shakespeare constituye la materialización de los dos últimos, de manera consciente o no. Por ello, a diferencia de la tendencia habitual de la crítica por ofrecer análisis centrados en uno solo de los relatos ${ }^{3}$, propondremos una lectura conjunta de aquellos, lo que nos permitirá mostrar que el volumen posee una estructura más compacta y trabada de lo que se pudiera pensar en un principio, pese a que en su origen fueron publicados de manera independiente en diversas revistas. No obstante, el hecho de que aparezcan reunidos bajo un mismo título en las Obras Completas y en ediciones posteriores, título que se corresponde además con el relato homónimo que rinde tributo a Shakespeare, nos inclina a pensar que tal vez tras esa decisión subyace un propósito que va más allá de la mera agrupación de tales ficciones en un libro, y más afín a sus deseos de los años sesenta — «"[...] escribir por lo menos [..., un libro] sobre Shakespeare, y [...otro] que sería una especie de testamento literario"». En este sentido, se debe recordar la dedicación y el cuidado que puso siempre Borges en la configuración de su obra, «[...] un Borges que revisó sus textos a lo largo de su vida, al ritmo de las reediciones y de las antologías, [y a quien] el proyecto editorial de las Obras Completas ofreci[ó] la oportunidad de una última y definitiva revisión (exclusiones o reintegraciones, enmiendas...) [...]» de sus escritos (Lefere, 2005: 171).

Así pues, antes de dar paso a nuestra interpretación de La memoria de Shakespeare, convendría recordar una premisa esencial en la poética borgeana, la de que la literatura no tiene un fin meramente estético. De ahí, que Borges llegase a

anticipa[r] de algún modo el camino que habría de recorrer la crítica literaria desde una ciencia interesada por el procedimiento artístico-verbal del mensaje, de tradición formalista y estructuralista, hacia una ciencia interesada por el hecho literario entendido como hecho comunicativo en el que el lector acaba desarrollando un papel fundamental (Gil Guerrero, 2008: 47) ${ }^{4}$.

3 Para «La memoria de Shakespeare», véanse los trabajos de Vázquez (1990: 479-487) y Víctor Manuel Sanchis Amat (2017: 131-146), y sobre «Veinticinco de agosto, 1983» véanse los comentarios de Robin Lefere (2005: 136) y Vicenzo Vitiello (2007: 54-58).

4 Las conclusiones de Gil Guerrero (2008: 47-63) seguirán derroteros distintos a los nuestros. 
Por consiguiente, se infiere que el lector, «ante el libro, se impone una disciplina precisa/ y lo hace en pos de un conocimiento preciso» (II: 394). Este papel activo del receptor de toda pieza literaria ya había sido sugerido años atrás en «Abenjacán el Bojarí, muerto en su laberinto». Este relato que, según parece, no contó con una buena acogida entre el público próximo a Borges - como se desprende de la postdata del epílogo (I: 629) - , nos parece bastante significativo para resaltar la importancia que concedía tanto a la capacidad hermenéutica del destinatario de toda historia, como a la necesidad de reflexionar sobre aquella para desentrañar su auténtico significado (o, al menos, para desarrollar una lectura coherente). En nuestra opinión, este es el sentido principal de la inquietante narración. En ella, Dunraven informa a Unwin de un extraño suceso que acaeció «un cuarto de siglo» antes de su conversación: la muerte de Abenjacán, de un esclavo y de un león a manos supuestamente del fantasma de Zaid (quien habría vengado así su muerte ocasionada por el primero). En vista de la inverosimilitud del cuento y de la incapacidad de Dunraven de dar a priori con una respuesta lógica, Unwin replica sin ningún atisbo de duda: «No sé si es explicable o inexplicable. Sé que es mentira» (I: 603), reacción que generó un malestar ostensible en su amigo. No obstante, tras una noche entera meditando al respecto, Unwin esboza una solución posible que acabará convenciendo a su interlocutor. Así, en consonancia con este final, se podría decir que a lo largo de su obra Borges establece una relación metonímica entre sus personajes, el lector y él, de modo que cualquier lector termine identificándose con Unwin, mientras que Borges no cesa de proyectarse en un Dunraven universal a lo largo de su ficción ${ }^{5}$.

De esta manera, una vez subrayado el papel primordial que adquieren la lectura y el rol activo del lector, daremos comienzo a nuestro comentario

\footnotetext{
5 En la obra borgeana son incontables las veces en que el narrador - muchas veces alter ego del autorse nos presenta como mero intermediario de una historia que le ha sido referida por otra persona, cuya legitimidad con la versión oficial no es absoluta, debido, en general, a «las inevitables variaciones que traen el tiempo y la buena o mala literatura» (II: 417). En ocasiones, la broma le cuesta una reprimenda de los propios personajes, como en el cuento de «Juan Muraña». Aquí, Emilio Trápani espeta al narrador principal: «Me prestaron tu libro sobre Carriego. Ahí hablás todo el tiempo de malevos; decime, Borges, vos, ¿qué podés saber de malevos?» (II: 422). Este juego, que es una constante en los relatos que conforman El informe de Brodie, también lo podemos encontrar en algún volumen de poemas (véase II: 504 y 505). La importancia de «Abenjacán...», por tanto, radica en la acción del destinatario último de la historia, ajeno por completo a ella, como sucede con el lector de Borges, que se detiene a reflexionar para juzgarla de manera crítica, tal y como debería hacer todo aquel que se sumerja en su obra.
} 
sobre La memoria de Shakespeare. Este volumen «comprende tres cuentos aparecidos en distintas publicaciones, anteriores a 1983, y un cuento» (III: 375) de 1980 que da título a la colección. El menor interés que ha despertado su última etapa narrativa ha motivado que sean escasos los estudios centrados en ella. Es más, incluso algunas monografías que dicen haber abarcado la totalidad del género, no han contado con La memoria de Shakespeare, como es el caso del trabajo ya citado de Gil Guerrero. Dicha crítica, por un lado, da por concluida esa parte de la producción borgeana con El informe de Brodie (1970) y El libro de arena (1975), mientras, por otro, propone dos razones para ese descuido voluntario por parte de la crítica:

Es una constante en los estudios borgianos el olvido o desatención de esta última etapa narrativa del autor. Este hecho puede explicarse, por un lado, por la gran sombra que lo que se conoce como puramente borgiano, a saber, Ficciones y El Aleph, explayó sobre el resto de su producción cuentística. Por otro lado, hay que tener en cuenta que si en la década del cuarenta en el panorama argentino es el género cuento el que disfruta de mayor apogeo, a partir de los sesenta la novela emerge como género predilecto no sólo para los escritores, sino para la crítica que dirige su atención fundamentalmente hacia él (Gil Guerrero, 2008: 161).

La primera pieza narrativa del libro es «Veinticinco de agosto, 1983». Como en «El otro» - cuento que sirve de apertura a El libro de arena-, en «Veinticinco» se abordan dos temas fundamentales en la obra del argentino: la problemática del doble y el tópico calderoniano de la vida es sueño (maravillosamente abordado ya en «Las ruinas circulares»). Esto último parece redimir el efecto fantástico que se había logrado con el desdoblamiento del personaje y la zozobra que este experimenta ante el extraordinario suceso ${ }^{6}$, pues, si se trata de un sueño - como en ambos casos parece aceptarse - el acontecimiento inusual podría ser explicado racionalmente y, por tanto, se anularía la condición de lo fantástico en el relato (Fernández, 2001: 285-286).

En cualquier caso, a la hora de interpretar «Veinticinco...», principalmente se ha incidido en una lectura biográfica, según la cual, a raíz de una crisis existencial, Borges habría tanteado la idea del suicidio, «como había ocurrido varias veces en el pasado cuando no podía encontrarle sentido a la vida»

6 David Roas (2001: 30), como buena parte de los estudiosos del género, coincide en que el miedo -la «inquietud», mejor dicho - es el efecto fundamental de lo fantástico. 
(Williamson, 2004: 471). Ahora bien, al margen de dicha interpretación, el relato ofrece una concomitancia más con «El otro» aparte de las dos ya mencionadas: la alusión a la propia producción borgeana. Así, si contrastamos los dos comentarios, comprobamos que mientras que en «El otro» este es escueto y se habla de una obra inconclusa ${ }^{7}$; en «Veinticinco...» dicho comentario adquiere un valor más relevante, puesto que con él no solo se confiesa el gran pesar que atormentaba al Borges narrador, sino que además sirve para emitir un juicio global de su creación hasta entonces:

Hacia 1979 comprenderás que tu supuesta obra no es otra cosa que una serie de borradores, de borradores misceláneos, y cederás a la vana y supersticiosa tentación de escribir tu gran libro. La superstición que nos ha infligido el Fausto de Goethe, Salammbô, el Ulysses. Llené, increíblemente muchas páginas.

-Y al final comprendiste que habías fracasado.

- Algo peor. Comprendí que era una obra maestra en el sentido más abrumador de la palabra. Mis buenas intenciones no habían pasado de las primeras páginas; en las otras estaban los laberintos, los cuchillos, el hombre que se cree una imagen, el reflejo que se cree verdadero, el tigre de las noches, las batallas que vuelven en la sangre, Juan Muraña ciego y fatal, la voz de Macedonio, la nave hecha con las uñas de los muertos, el inglés antiguo repetido en las tardes. [...] Además, los falsos recuerdos, el doble juego de los símbolos, las largas enumeraciones, el buen manejo del prosaísmo, las simetrías imperfectas que descubren con alborozo los críticos, las citas no siempre apócrifas (III: 379).

Así, en consonancia con lo anterior, acaso quepa pensar que, en un momento en que el autor advierte que su final se acerca, este se detenga a pensar en aquello que quedará tras de sí, o lo que es lo mismo, en su legado literario. En efecto, tal planteamiento parece coherente con el propósito del autor, quien «a mitad de los años veinte, ya se había formulado la convicción fundamental [...] de que lo esencial no son las circunstancias y peripecias vitales en las

\footnotetext{
7 «No sé la cifra de los libros que escribirás, pero sé que son demasiados. Escribirás poesías que te darán un agrado no compartido y cuentos de índole fantástica [...] Me agradó que nada me preguntase sobre el fracaso o éxito de los libros» (III: 13). No debemos olvidar, claro, que el interlocutor es un joven Borges allá por 1918; mientras que en «Veinticinco...» se invertirán los papeles: el narrador es quien se dirige a su «yo» futuro, no al pretérito. Con todo, no creemos que sea casual esta alternancia de perspectivas, como se deducirá de nuestro comentario posterior.
} 
que suelen complacerse los biógrafos, sino la vida mental y, sobre todo, las obras que ésta ha generado [...]» (Lefere, 2005: 146). Esta idea probablemente la comparten también muchos de sus lectores, como es el caso de Octavio Paz (1914-1998), quien tras la muerte del argentino declaró que «"[...] hoy Borges ha vuelto a ser lo que era cuando yo tenía veinte años: unos libros, una obra" » (Paz en Fernández, 1999: 86).

Una vez que ha incidido en algunos puntos clave de su universo narrativo en el fragmento arriba transcrito, el autor debe dejar patente que está elaborando una especie de testamento literario. Esto es, ha llegado casi a la culminación de su itinerario y es, por tanto, el momento de ir preparando - en términos simbólicos - la entrega de su legado, puesto que Borges, valiéndonos de la terminología de Bloom, se ha convertido en un «Gran Original»y, por consiguiente, en un referente de la literatura universal - algo de lo que era plenamente consciente. En nuestra opinión, es en ese contexto en el que se inscribe la siguiente pieza de la colección, «Tigres azules».

En «Tigres azules», Craigie, un profesor que siente desde niño una tremenda fascinación por dichos animales, se verá envuelto en una aventura a cuyo clímax se llegará con su sorprendente hallazgo: en vez de un tigre azul como pretendía, descubrirá unos discos mágicos del mismo color que se multiplican sin cesar. Con el tiempo, la posesión de dichos objetos generará en él tal sensación de angustia que anhelará con vehemencia desprenderse de ellos. La oportunidad se le brindará con la aparición de un mendigo. Este, a modo de limosna, le pedirá a Craigie que le entregue todas las piedras que lleva consigo, pues «el que no ha dado todo no ha dado nada» (III: 388); demanda que mantendrá incluso tras la advertencia de Craigie de lo temible de su donativo, puesto que el mendigo está plenamente convencido de que en ningún caso él saldrá perjudicado: «No sé aún cuál es tu limosna, pero la mía es espantosa. Te quedas con los días y las noches, con la cordura, con los hábitos, con el mundo» (III: 388).

Este final, de acuerdo con Edwin Williamson (2004: 477), revela la recuperación de la cordura por parte de Craigie a cambio de cesar en su empeño de «alcanzar el Absoluto» ${ }^{8}$. Asimismo, a raíz del comentario del mendigo,

8 Para Williamson (2004: 476), «la preocupación de Borges con los tigres, como la de Alexander Craigie, retrocedía a los más antiguos días de su infancia. Sus orígenes residen tanto en su deseo de escapar del sentido de indignidad infligido por la espada del honor de su madre como el solipsismo fomentado por 
apunta que hay «un indicio de que en el acto de rendirse a otro, uno puede descubrir el medio de reconciliarse con "la cordura, con los hábitos, con el mundo" ». Desde nuestro punto de vista, la interpretación del biógrafo no es del todo precisa: en primer lugar, cabría recordar que el protagonista en ningún momento ha sido partícipe de la locura: «Al principio yo había sufrido el temor de estar loco; con el tiempo creo que hubiera preferido estar loco, ya que mi alucinación personal importaría menos que la prueba de que en el universo cabe el desorden ${ }^{9}$ (III: 386). En segundo lugar, respecto a la acción de Craigie, convendría matizar que no es tal como la entiende Williamson, ya que Craigie no se rinde a otra persona, sino que su acción consiste en entregar al mendigo (en su totalidad) algo de su propiedad, algo que posee atributos mágicos y que se multiplica indefinidamente sin manera de interrumpir el proceso. Lo mismo sucede, por ejemplo, con el lenguaje literario, que «es plural por esencia», «porque, en él, el signo lingüístico es portador de múltiples dimensiones semánticas y tiende a una multivalencia significativa, huyendo del significado unívoco, que es propio de los lenguajes monosignificativos (discurso lógico, lenguaje jurídico, etc.)» (Aguiar e Silva, 1967: 20-23).

Finalmente, tampoco se debe olvidar que el mendigo advertirá al protagonista de que su limosna es aún peor. Llegados a este punto, acaso cabría preguntarse el porqué de dicha advertencia, ¿por qué la suya es «más espantosa» si en verdad no se produce intercambio alguno entre los dos personajes? En nuestra opinión, la clave no reside en lo que el mendigo le aporta, sino en lo que niega a Craigie al desposeerlo de los discos; es decir, la «limosna» del mendigo consiste en adueñarse del componente literario - mágico - que da

\footnotetext{
la biblioteca de su padre. El tigre parecía encarnar un estado del yo realizado, y Borges, en consecuencia, había buscado conectarse con el tigre por diversos medios sucesivos. Pero en "Tigres azules", Borges [...] Había magnificado y dramatizado su fascinación infantil con los tigres en una búsqueda de unión con el Absoluto, empleando diversas figuras poéticas [...] para representar esa experiencia sublime. Sin embargo, buscar semejante meta era aspirar a una forma de ser sólo propia de Dios».

9 Dicho desorden alude a los discos, objetos cuyo número variaba inexplicablemente: «Miraba con fijeza cualquiera de ellos, lo sacaba con el pulgar y el índice y cuando estaba solo, eran muchos» (III: 384). Dado que a continuación vamos a plantear una asociación simbólica entre el disco y la palabra, por un lado, y que más adelante mencionaremos la existencia de un término único capaz de expresar el universo, por otro, creemos necesario indicar que según sus relatos «el desorden» puede darse tanto en el universo (propiciado por los «discos») como en el poema (en función del uso de las «palabras»); esto último se puede comprobar en la segunda loa recitada y aclamada por el poeta que protagoniza «El espejo y la máscara» (III: 46). De este modo, cabría deducir la existencia de un vínculo simbólico entre los discos y las palabras, únicas entidades capaces de alterar el orden establecido, según la ficción de Borges.
} 
sentido a la vida ${ }^{10}$. Así, Craigie será devuelto a su rutinaria realidad de profesor universitario «con los días y las noches, con la cordura, con los hábitos, con el mundo» (III: 388). Los tres términos subrayados son fundamentales, pues, tal vez, nos conduzcan al universo virtual del Borges lector y creador. En nuestra opinión, la adquisición de la supuesta «cordura» para Craigie, no debe entenderse como la pérdida de la locura en sentido patológico, pues el personaje no la ha padecido nunca, sino, más bien, de «[...] la "locura" poética de que habla Platón [en el Fedro]», entendida esta como «una "bendición" que relaciona al poeta con lo trascendente» (Aguiar e Silva, 1967: 121-122) ${ }^{11}$. Es decir, al recuperar la cordura Craigie, su capacidad creativa se verá neutralizada, independientemente de si alguna vez ha hecho (o hará) uso de ella. Respecto a los otros dos términos subrayados, debemos recordar que la obra de Borges no se caracteriza precisamente por su carácter costumbrista o por estar apegada al «mundo», esto es, por su esencia realista ${ }^{12}$ - más bien es atí-

10 Recordemos la cita de «El Inmortal» que encabeza nuestro trabajo, tan significativa para nuestra lectura: «Palabras, palabras desplazadas y mutiladas, palabras de otros, fue la pobre limosna que le dejaron las horas y los siglos» (I: 544, el subrayado es nuestro); así como las concomitancias entre el pasaje arriba analizado y sus consecuencias con el final de «La memoria de Shakespeare»: por un lado, la advertencia de Soergel al ignoto hombre a quien se dirige por teléfono para ofrecerle la memoria del bardo británico («Sé que lo que te ofrezco es muy grave. Piénsalo bien»), y, por otro, la posdata final del relato, una vez que el personaje se ha liberado de su carga: «Ya soy un hombre entre los hombres. En la vigilia soy el profesor emérito Hermann Soergel, que manejo un fichero y que redacto trivialidades eruditas [...]» (III: 398-399).

11 «"...] El tercer grado de locura y de posesión viene de las Musas, cuando se hacen con un alma tierna e impecable, despertándola y alentándola hacia cantos y toda clase de poesía, que al ensalzar mil hechos de los antiguos, educa a los que han de venir. Aquel, pues, que sin la locura de las musas acude a las puertas de la poesía, persuadido de que, como por arte, va a hacerse un verdadero poeta, lo será imperfecto, y la obra que sea capaz de crear, estando en su sano juicio, quedará eclipsada por la de los inspirados y posesos [...]" " (Platón, 1986: 342). «Esta visión del poeta y de la creación poética influyó marcadamente en las teorías literarias de la cultura occidental [...], su presencia puede rastrearse a lo largo de los siglos, desde la Edad Media hasta los tiempos más próximos, aunque en formas diversas. Constituyó siempre un elemento de magnificación del poeta, por la relación que establece entre éste y un poder trascendente, de preservación del misterio de la poesía, gracias al carácter sacral de que la reviste, y un elemento de repudio del formalismo y del academicismo» (Aguiar e Silva, 1967: 122). En efecto, en 1969 Borges apuntaba en el prólogo de Cuaderno San Martín (1929): «He hablado mucho, he hablado demasiado, sobre la poesía como brusco don del Espíritu, [...]» (I: 79).

12 Precisamente, esto último fue una de sus innovaciones más valoradas entre sus contemporáneos hispanoamericanos, como lo prueban las palabras del poeta y crítico mexicano Xavier Villaurrutia (19031950), a quien la publicación de Ficciones le «[...] llevó a pensar que mientras otras literaturas hispanoamericanas, sin descontar la nuestra, fatigan sus pasos en el desierto de un realismo y de un naturalismo áridos y secos, monótonos e interminables, la literatura argentina presenta ante nuestros ojos, no un espejismo sino un verdadero oasis para nuestra sed de literatura de invención [..., que] recobra sus derechos que al menos aquí, en México, se le niegan. Porque lo cierto es que, entre nosotros, al autor que no aborda temas realistas y que no se ocupa de la realidad nuestra de cada día, se le acusa de deshumanizado, de purista, y aun de cosas peores» (Villaurrutia, 1953: 887). Tal vez, Villaurrutia nos esté dando las claves para abrir una investigación necesaria sobre el impacto que tuvo Borges en la poética mexicana de por aquel entonces, y que se sume a los esfuerzos de Rafael Olea Franco (véase la nota 19 del presente trabajo). 
pica, con un despliegue de tramas, escenarios, personajes, tiempos, etc., de lo más variopinto. Así, en consonancia con todo lo anterior, cabría entender la limosna en términos semejantes a los expuestos en «El Inmortal». De este modo, ¿cómo no iba a ser más espantosa para Borges la limosna del mendigo que la de Craigie? ¿Qué puede haber más funesto para alguien, cuya «vida [...] sólo llega a ser vida al llegar a ser literatura» (Nahson, 2009: 45), que el hecho de que lo despojen de esta? Alguien cuyos «más íntimos anhelos» consisten en «leer para vivir y hacer poesía, y sentir para escribir y soñar» (2009: 65).

Conscientes de lo aventurado de nuestra hipótesis, trataremos de reforzar nuestra teoría aún más con los dos relatos que cierran la serie. En «La rosa del Paracelso», uno extrae la sensación de que ya desde el párrafo inicial se establece un enlace con el cuento previo, puesto que en ambos casos se solicitará socorro a una divinidad indefinida, socorro que no tardará en materializarse en forma de hombre ${ }^{13}$. Dicho vínculo entre ambos relatos se acentuará al confesar el aprendiz de «La rosa...» el auténtico motivo de su llegada: «Quiero que me enseñes el Arte. Quiero recorrer a tu lado el camino que conduce a la Piedra» (III: 389). Como se puede comprobar, en este caso, la simbología es más explícita que en «Tigres azules»: la asociación entre la Piedra y el Arte (la palabra y la poesía) ${ }^{14}$, así como los roles de maestro y de discípulo. Ahora bien, a pesar de la predisposición del segundo para embarcarse en una aventura de tal envergadura, el final termina con la separación

\footnotetext{
13 «Tigres azules» terminaba con el protagonista pidiendo a «Dios y Alá» socorro. Su reclamo llegará en forma de hombre, como lo confirman las palabras del mendigo nada más atisbarle: «He venido» (III: 388). Por otro lado, en el comienzo de «La rosa...» leemos: «En su taller [...], Paracelso pidió a su Dios, a su indeterminado Dios, a cualquier Dios, que le enviara un discípulo» (III: 389).

14 Nos ha llamado la atención que en «El Aleph» se baraje la posibilidad de que el universo se recoja dentro de una piedra (I: 627-628) y que, a su vez, en «La escritura de un Dios» se acepte la existencia de una sola «palabra» capaz de expresar «la plenitud»; es decir, un término único que, en ningún caso, «puede ser inferior al universo o menos que la suma del tiempo. Sombras o simulacros de esa voz que equivale a un lenguaje y a cuanto puede comprender un lenguaje son las ambiciosas y pobres voces humanas, todo, mundo, universo» (I: 598). En ambos casos se podría establecer, por tanto, un vínculo entre la piedra y la palabra, dos entidades capaces de contener por sí solas el cosmos. Es más, acerca del segundo relato, cabría recoger las palabras del poeta serbio Vasko Popa (1922-1991) en "Cosas de poetas», que podrían contribuir a comprender el sentido del relato borgeano: «Tú no quieres que tus palabras queden apenas como nombres y apellidos de las cosas. A ti te gustaría que tus palabras fueran las cosas y la creación misma. Después de todo, así te comportas con ellas.// Borras, borras todo en el mundo hasta quedarte solo con las palabras. Y entonces, ellas no tienen otra salida. Tienen que volverse todo. Todo en el mundo. Todas las cosas. Entonces, tú eres su dios: porque tampoco tú, entonces, tienes otra salida// Y solo entonces es cuando empieza la verdadera empresa que tiene que revelar lo que tú puedes hacer con las palabras y lo que las palabras pueden aguantar que se haga con ellas...» (Popa, 2012: 495).
} 
de ambos, dejando un interrogante abierto al lector. Quizás, como se sugiere en «Undr» (III: 50) y como propone Bloom (1973: 63) en un contexto parejo, dicho final se deba a que el poeta, tras haber entrado en contacto con quien sí posee el secreto (el «Gran Original»), debe buscar por sí mismo «la Palabra»; esto es, debe desvincularse de su maestro para poder cantar «con una palabra distinta» (III: 51).

Finalmente, el relato que cierra la colección y le da título es «La memoria de Shakespeare». En esta pieza narrativa parece sintetizarse todo lo expuesto anteriormente con el trasvase simbólico de la memoria del autor de Hamlet de una persona a otra, «desde los días más pueriles y antiguos hasta los del principio de abril de 1616» (III: 394). La elección de quien para muchos es el autor más grande de todos los tiempos y, tal vez, quien mejor encarne la idea de «ser» borgeana - ese ser «Everything and nothing» (II: 181-182), fruto de un sueño, de una invención cuya verdad quizás nunca se descubra (el enigma en torno a la figura y la autoría de las obras firmadas por Shakespeare sigue sin resolverse $\left.{ }^{15}\right)$ - no parece en absoluto fortuita. El legado del dramaturgo inglés, su memoria, pervive únicamente en sus textos. Es su literatura y no su biografía lo que ha perdurado en el tiempo ${ }^{16}$. Por ende, será su obra lo que se termine convirtiendo en motivo de obsesión y lo que termine eclipsando, temporalmente, al futuro escritor ${ }^{17}$, quien deberá realizar un esfuerzo inconmensurable para liberarse de la influencia recibida a fin de proseguir su camino para poder ser uno mismo ${ }^{18}$, para poder ser Jorge Luis Borges.

En suma, tal vez cabría plantearse la posibilidad de que, al final de su creación, el autor de Fervor de Buenos Aires se embarcase en una meditación definitiva sobre la resonancia póstuma que alcanzaría su obra y que labrase, de esa manera, un proyecto artístico que ya había concebido a comienzos de los años sesenta. Recordemos, en este sentido, que no hay «[...] nadie más con-

\footnotetext{
15 Para un estado actual de la polémica véase el libro de Paul Edmondson y Stanley Wells (2013).

16 A raíz de unos versos de Milton dedicados al bardo británico, Bloom (1994: 64) comenta que aquel «anticipa a Borges al ofrecernos un Shakespeare que, al ser todos, no es nadie en sí mismo, tan anónimo como la naturaleza. Si los lectores y el público, al igual que tus personajes e intérpretes, se han convertido en tu obra, tu libro, entonces sólo vives en ellos»; o, lo que es lo mismo, en su memoria. Así, no parece casual, por tanto, que las alusiones a los recuerdos estén directamente vinculadas a cuestiones literarias (III: 295-297) y que los personajes que adquieran la memoria de Shakespeare sean incapaces de componer su biografía.

17 «Con el tiempo, el gran río de Shakespeare amenazó, y casi anegó mi modesto caudal» (III: 398).

18 «Yo quería volver a ser Hermann Soergel» (III: 398).
} 
vencido que Borges del carácter reflexivo y no inmediato del arte», un Borges cuya «reflexión poética es [...] reflexión sobre la memoria, si no de la memoria, y es por lo tanto una reflexión sobre la reflexión. Así su arte se encuentra doblemente alejado de la vida: como arte y como reflexión sobre el arte - como arte que es, que nace como reflexión sobre el arte [...]» (Vitiello, 2007: 3334, el énfasis es nuestro). En consecuencia, esa misma meditación bien pudo haberse transmutado en uno de sus temas literarios fundamentales, como ya había sucedido en el pasado con otros motivos que captaron su atención. Borges, de este modo, a través de sus cuentos advierte a sus herederos y a sus futuros lectores no solo de la complejidad, sino también de los riesgos que implica asumir su legado: «Sé que lo que te ofrezco es muy grave. Piénsalo bien» (III: 398). Con todo, igual que sucede en sus relatos, Borges acepta que el efebo encuentre su camino, aunque eso suponga que los suyos sean «Los testamentos traicionados», si bien testamentos al fin y al cabo ${ }^{19}$. Es más, según nuestra lectura, con La memoria de Shakespeare su obra en prosa culminaría de manera coherente dentro de su producción, ya que «buena parte de Inquisiciones [su primer libro en prosa] aparece como el homenaje de un escritor clásico a sus inspiradores, a los que forjaron su voz literaria, en la que siguen latiendo» (Lefere, 2005: 42). Es decir, de acuerdo con lo anterior, en su prosa se vislumbra tanto una voluntad de cohesión interna como un afán de co-

\footnotetext{
19 No deja de ser llamativo que Milan Kundera (1929) no mencione ni una sola vez al escritor argentino en su sugerente libro sobre la tradición narrativa moderna desde Rabelais y Cervantes hasta la actualidad, de cuyo título nos hemos servido para el presente trabajo. Es probable que alguien tan lúcido y tan conocedor de la literatura más influyente del siglo xx también tenga deudas no explícitamente reconocidas con Borges. Este, desde luego, no sería el primer caso, ni el último, si bien no habría que llegar, por ejemplo, a los extremos del novelista mexicano actual Álvaro Enrigue (2013), quien por fin reconoció en una entrevista reciente (incluida en la bibliografía) que: «Absolutamente. Borges es un escritor tan importante para mí que me pasé toda la vida peleando para que no se me notara [...] Durante toda la vida me pasé borrando a Borges de lo que escribía, pero en este caso sentí que ya me podía dar el permiso de plancharlo con el placer con el que se plancha a Borges, el mejor prosista del siglo xx con Kafka y Joyce. No hay una figura más alta que Borges para mí». Precisamente, en el estudio de esas posibles deudas o vínculos de otros autores con Borges reside uno de los principales atractivos a día de hoy en el ámbito de la investigación de las letras hispanas. Así, por ejemplo, Olea Franco acusaba hace unos años la falta de estudios centrados en la relación de Borges con la literatura mexicana, «[...] tema que hasta el momento ha sido inexplorado, a excepción del caso de Alfonso Reyes [...]», vacío que comenzó a cubrir con dos lúcidos ensayos sobre los nexos entre Borges y Arreola, por un lado, y Borges y Pacheco, por otro - véase Olea Franco (2006a: 125-148; 2006b: 149-166), respectivamente; y que más recientemente ha continuado entre otros Reindert Dhondt (2015: 175-192), quien ha estudiado la recepción crítica y creativa de Borges en los ensayos de Carlos Fuentes. De hecho su ensayo se incluye en un volumen de consulta necesaria para quien quiera profundizar en los nexos o la recepción de la obra y el pensamiento borgeano con otras literaturas fuera del ámbito hispanoamericano, como la francesa, la española, la norteamericana o la alemana (véase Adriaensen et al., 2015).
} 
munión entre sus autores predilectos y sus lectores, a quienes Borges habrá dejado su legado en una concisa carta de despedida en forma de testamento literario, La memoria de Shakespeare, sirviéndose del género que le otorgó la fama universal e inmediata, el relato, y nutrida a su vez con algunas de las principales inquietudes que lo acompañaron en vida: la problemática del doble, los límites de lo fantástico, los interrogantes del sueño, el anhelo del absoluto, la meditación sobre el arte y el rescoldo de la memoria.

\section{REFERENCIAS BIBLIOGRÁFICAS:}

Adriaensen, Brigitte, Botterweg, Meike, Steenmeijer, Maarten y Wijnterp, Lies (2015), eds., Una profunda necesidad en la ficción contemporánea: la recepción de Borges en la república mundial de las letras, Madrid/Frankfurt, Iberoamericana/Vervuert.

Aguiar e Silva, Vítor Manuel de (1967), Teoría de la literatura, traducción de Valentín García Yebra , Madrid, Gredos, 1986 (1 ${ }^{\text {a }}$ ed., $7^{\mathrm{a}}$ reimpr.).

BLoom, Harold (1994), «Shakespeare, centro del canon», en El canon occidental. La escuela y los libros de todas las épocas, traducción de Damián Alou, Barcelona, Anagrama, 2002 (2ª ed.), págs. 55-86.

- (1973), La ansiedad de la influencia. Una teoría de la poesía, traducción de Javier Alcoriza y Antonio Lastra, Madrid, Trotta, 2009.

Borges, Jorge Luis (1989), Obras completas 1923-1949, vol.1, edición de Carlos V. Frías, Barcelona, Emecé.

- (1989), Obras completas 1952-1972, vol.2, edición de Carlos V. Frías, Barcelona, Emecé.

- (1989), Obras completas 1975-1985, vol.3, edición de Carlos V. Frías, Barcelona, Emecé.

Cuesta, Jorge (2003), Obras reunidas I. Poesía y traducciones de Éluard, Mallarmé, Spender y Donne, edición de Jesús R. Martínez Malo y Víctor Peláez Cuesta, prólogo de Francisco Segovia, México, FCE.

DHondt, Reindert (2015), «Carlos Fuentes, autor de "El Aleph": la recepción crítica y creativa de Borges en los ensayos de Carlos Fuentes», en Brigitte 
Adriaensen, Meike Botterweg, Maarten Steenmeijer y Lies Wijnterp, eds., Una profunda necesidad en la ficción contemporánea: la recepción de Borges en la república mundial de las letras, Madrid/Frankfurt, Iberoamericana/Vervuert, págs. 175-192.

Edmondson, Paul y Wells, Stanley, (2013), eds., La verdad sobre Shakespeare. Argumentos, evidencias y polémicas, traducción de Jorge García García y Carla López Fatur, Barcelona, Stella Maris, 2016.

ENRIgue, Álvaro (2013), «Quería trabajar en el límite de la novela», en Página 12. En línea: <https://www.pagina12.com.ar/diario/suplementos/espectaculos/4-30783-2013-1210.html>. Último acceso el 01-oct-2018.

FERNÁNDEZ, Teodosio (1999), Álbum biográfico y fotográfico de Jorge Luis Borges, Madrid, Alianza.

- (2001), «Lo real maravilloso de América y la literatura fantástica», en David Roas, coord., Teorías de lo fantástico, Madrid, Arco Libros, págs. 283300 .

Gil Guerrero, Herminia (2008), Poética narrativa de Jorge Luis Borges, Madrid/ Frankfurt, Iberoamericana/Vervuert.

HERBERT, Zbigniew (1973), El laberinto junto al mar, traducción de Anna Rubió Rodón y Jerzy Sławomirski, Barcelona, Acantilado, 2013.

LEFERE, Robin (2005), Borges, entre autorretrato y automitografía, Madrid, Gredos.

NAHSON, Daniel (2009), «La literatura como palimpsesto de un sueño autobiográfico», en La crítica del mito: Borges y la literatura como sueño de vida, Madrid/Frankfurt, Iberoamericana/Vervuert, págs. 39-65.

Olea Franco, Rafael (2006a), «Un diálogo posible: Borges y Arreola», en Los dones literarios de Borges, Madrid/Frankfurt, Iberoamericana/Vervuert, págs. 125-148.

- (2006b), «Borges en Pacheco», en Los dones literarios de Borges, Madrid/ Frankfurt, Iberoamericana/Vervuert, págs. 149-166. 
Platón (1986), Diálogos, III: Fedón, Banquete, Fedro, traducciones, introducciones y notas por Carlos García Gual, M. Martínez Hernández y E. Lledó Íñigo, Madrid, Gredos.

Popa, Vasko (2012), El cansancio ajeno. Poesía completa, traducción de Dubravka Sužnjević, Madrid-México, Vaso Roto.

RoAs, David (2001), «La amenaza de lo fantástico», en David Roas, coord., Teorías de lo fantástico, Madrid, Arco Libros, págs.7-46.

SANCHIS AMAT, Víctor Manuel (2017), «La literatura que se muerde la cola: Jorge Luis Borges y la obsesión del lector en "La memoria de Shakespeare"», en Vicente Cervera Salinas y María Dolores Adsuar Fernández, coords., Avatares del Hacedor: Jorge Luis Borges (1986-2016), Madrid, Verbum, págs. 131-146.

VÁzQueZ, María Esther (1990), «"La memoria de Shakespeare”: el último juego de Borges», en Revista Iberoamericana, 151, págs. 479-487. En línea: <https://revista-iberoamericana.pitt.edu/ojs/index.php/Iberoamericana/ article/view/4726/4888>. Último acceso el 29-dec-2018.

Villaurrutia, Xavier (1953), «Tres notas sobre Jorge Luis Borges», en Obras: poesía, teatro, prosas varias, crítica, prólogo de Alí Chumacero, recopilación de textos por Miguel Capistrán, Alí Chumacero y Luis Mario Schneider, bibliografía de Xavier Villaurrutia por Luis Mario Schneider, México, FCE, 1996 (3 ${ }^{\text {a }}$ ed., $2^{\text {a }}$ reimpr.), págs. 885-889.

Vitiello, Vicenzo (2007), Borges. Memoria y lenguaje, traducciones de Julio Pérez Ugena, Cuqui Weller, Carolina del Olmo y César Rendueles, Madrid, Círculo de Bellas Artes.

Williamson, Edwin (2004), Borges, una vida, traducción de Elvio Eduardo Gandolfo, Barcelona, Seix Barral, 2006. 